\title{
Peningkatan Pemberdayaan Perempuan dalam Pembuatan Kepeng Waluh Guna untuk Meningkatkan Perekonomian di Desa Patean Kecamatan Batuan
}

\author{
Yayuk Sugiarti ${ }^{1)}$, Sutrisni ${ }^{2)}$ \\ Fakultas Hukum, Universitas Wiraraja \\ E-mail : yayuksugiarti@wiraraja.ac.id ${ }^{1)}$, sutrisnioke@ @ahoo.com ${ }^{2)}$
}

\begin{abstract}
Abstrak
Pemberdayaan perempuan merupakan usaha sistematis dan terencana untuk mencapai kesetaraan dan keadilan gender dalam kehidupan keluarga dan masyarakat. Salah satu kegiatan pemberdayaan perempuan di Desa Patean Kecamatan Batuan yaitu pelatihan pembuatan labu kuning menjadi kepeng (kepeng waluh). Adanya pemberdayaan ini dapat mendorong para perempuan di Desa Patean untuk dapat membuka peluang usaha mengolah labu menjadi kepeng guna untuk meningkatkan perekonomian. Tujuan adanya pengabdian kepada masyarakat ini adalah untuk memberikan pengetahuan berupa pelatihan mengolah labu kuning (waluh) menjadi kepeng untuk meningkatkan harga jual di pasar sehingga berpengaruh terhadap kesejahteraan keluarga di Desa Patean Kecamatan Batuan. Pengabdian kepada masyarakat ini menggunakan metode pelatihan yaitu ceramah digunakan untuk menjelaskan tentang teori bermacam-macam tentang pengolahan labu kuning; metode praktek digunakan untuk mempraktekkan berbagai macam pengolahan labu kuning menjadi kepeng waloh; serta metode diskusi dilakukan setelah pelatihan selesai sehingga kita mengetahui sejauh mana respon peserta terhadap kegiatan pengabdian ini. Adanya pelatihan buah siwalan menjadi manisan ini, mampu memberdayakan perempuan dengan cara melakukan pelatihan pengolahan mengolah labu kuning menjadi kepeng sehingga dapat mewujudkan desa mandiri dan dapat meningkatkan ekonomi masyarakat Desa Patean Kecamatan Batuan.
\end{abstract}

Kata kunci : pemberdayaan, perempuan, kepeng waluh

\section{Pendahuluan}

Perempuan pada dasarnya mempunyai peran yang beragam, salah satunya yaitu banyak berperan sebagai laki-laki dalam mencari nafkah keluarga. Hal ini dikarenakan pendapatan suami yang rendah (paspasan) sehingga mendorong para perempuan untuk membantu menambah pendapatan keluarga. Apalagi akibat adanya Covid 19 ini banyak kepala keluarga yang kehilangan pekerjaannya sehingga hal ini menuntut kita sebagai perempuan untuk ikut andil dalam mencari nafkah. Adanya persoalan yang dihadapi perempuan di desa, kami melakukan pemberdayaan dan salah satu desa yang dijadikan sasaran yaitu Desa Patean Kecamatan Batuan Kabupaten Sumenep. Desa Patean merupakan salah satu desa yang mayoritas sebagai petani, mereka sehari-hari menghabiskan waktunya untuk mengolah sawah (di sektor pertanian), namun dirasa tidak cukup 
serta ikut berkontribusi dalam

dalam memenuhi kebutuhan rumah tangga. Adanya kegiatan pengabdian ini, kami berupaya agar perempuan di Desa Patean mengatasi waktu luangnya untuk melakukan hal yang bermanfaat dengan cara memberikan pelatihan pembuatan kepeng waluh guna untuk meningkatkan perekonomian.

Tanaman labu tumbuh subur di daerah Patean dan tidak perlu menunggu lama untuk panen. Masyarakat bisa memanfaatkan halaman rumah yang luas untuk bisa ditanami labu. Labu kuning salah satu tanaman yang mudah dalam pembibitan, perawatan, dan hasilnya cukup memberikan nilai ekonomis yang tinggi kepada masyarakat salah satunya labu tersebut bisa dijadikan camilan ringan diolah menjadi kepeng.

Selama ini masyarakat tidak mengetahui bahwa labu dapat dijadikan kepeng yang mempunyai nilai ekonomis tinggi. Bahan baku juga mudah didapat dan prosesnya mudah. Adanya pemberdayaan ini dapat mendorong para perempuan di Desa Patean Kecamatan Batuan untuk dapat membuka peluang usaha mengolah labu menjadi kepeng (kepeng waluh) dan nantinya dapat dijual di pasar

meningkatkan perekonomian keluarga.

\section{Metode}

Kegiatan pengabdian ini dilaksanakan di Desa Patean Kecamatan Batuan yang berjarak kurang lebih $1 \mathrm{~km}$ dari Universitas Wiraraja tepatnya di rumah Ibu Ketua RT 02/RW 01 yaitu Ibu Lailatus Ratniyati Desa Patean Kecamatan Batuan dilaksanakan pada bulan April - September 2020 diikuti oleh tim PKM serta 4 orang mahasiswa. Kegiatan ini diikuti pula oleh 30 orang ibu-ibu yang sehari-hari sebagai ibu rumah tangga yang merasakan dampak dari pandemi Covid 19. Pelatihan ini menggunakan metode ceramah menjelaskan tentang teori bermacammacam pengolahan labu kuning; metode praktek digunakan untuk mempraktekkan pengolahan labu kuning menjadi kepeng waloh; dan metode diskusi dilakukan setelah pelatihan selesai sehingga kita mengetahui sejauh mana respon peserta terhadap kegiatan pengabdian ini.

\section{Hasil dan Pembahasan}


masyarakat di Desa Patean Kecamatan Batuan.

Pemberdayaan yang dilakukan oleh tim PKM Universitas Wiraraja melalui pelatihan pengolahan waluh menjadi kepeng yaitu dengan cara

yang paling dirasakan adalah penurunan tingkat pendapatan dan daya beli masyarakat terhadap kebutuhan hidupnya. Sehubungan dengan hal tersebut, maka upaya mengembangkan sumber daya untuk meningkatkan pendapatan yaitu dengan cara pemberdayaan.

Tujuan tim PKM Universitas Wiraraja melakukan pemberdayaan perempuan melalui pembuatan kepeng waluh dalam meningkatkan perekonomian di Desa Patean Kecamatan Batuan yaitu untuk meningkatkan kemandirian masyarakat dalam mengolah sumberdaya yang ada sesuai dengan kondisi sosial dan budaya yang seimbang dari aspek ekologis dan ekonomis. Desa Patean merupakan desa yang cocok untuk ditanami tanaman waluh, dan ini berpeluang besar untuk dijadikan peluang dalam meningkatkan nilai guna dari tumbuhan waluh menjadi kepeng. serta dapat meningkatkan partisipasi masyarakat dengan mengembangkan kelembagaan

\section{Tahap Persiapan}

Pelatihan ini dimulai dengan tahap persiapan, yaitu tim PKM berkordinasi dengan Ibu Lailatus Ratniyati terkait akan diadakan kegiatan pelatihan pemberdayaan perempuan melalui pelatihan pembuatan waluh menjadi kepeng. Ibu Laila sangat antusias, dan berharap warga di desa Patean dapat mengikuti pelatihan tersebut dengan baik. Ini merupakan salah satu cara dalam peningkatan kesejathteraan masyarakat, karena waluh tersebut mudah didapatkan di Desa Patean Kecamatan Batuan.

\section{Tahap Pelaksanaan}

Kegiatan pemberdayaan perempuan menjadi kepeng dimulai dari pukul 15.00 dan berakhir pukul 17.00 WIB. Kegiatan ini dilakukan di kediaman Ibu Laila selaku ketua RT di Desa Patean Kecamatan Batuan. Peserta yang hadir meliputi ibu-ibu muda, anak remaja dan lanjut usia. Mereka sangat antusias dan bersemangat mengikuti pelatihan waluh ini. Selama ini mereka melalui pelatihan pembuatan waluh 
dengan mengembangkan kelembagaan

menganggap waluh hanya bisa dijual dalam bentuk buahnya saja, tanpa pernah tahu kalau walau bisa dijadikan kepeng dan makanan lainnya yang nantinya mempunyai nilai jual dan bisa meningkatkan pendapatan mereka.

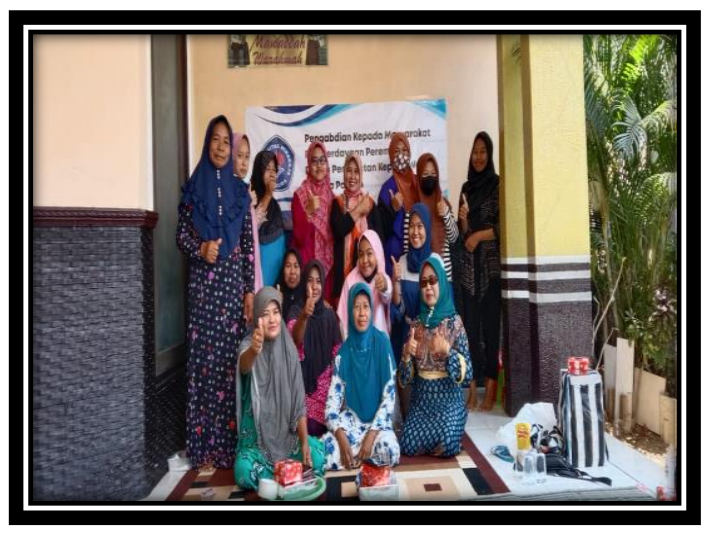

Gambar. Pelatihan pembuatan kepeng waluh

\section{Simpulan}

Berdasarkan pelatihan yang telah kami lakukan di Desa Banuaju Timur Kecamatan Batang-Batang, maka tim menyimpulkan sebagai berikut:

a. Kegiatan Pemberdayaan perempuan melalui pelatihan pembuatan labu kuning menjadi kepeng waluh, mampu meningkatkan partisipasi masyarakat masyarakat;

b. Meningkatkan kemandirian masyarakat dalam mengolah sumberdaya yang ada sesuai dengan kondisi sosial dan budaya yang seimbang dari aspek ekologis dan ekonomis;

c. Mampu menambah pendapatan mereka untuk kebutuhan sehari-hari dengan mengolah labu kuning (waluh) menjadi kepeng di masa pandemi Covid 19 ini.

\section{Daftar Pustaka}

Agusta, I. 2002. Metode Evaluasi

Program Pemberdayaan. Humaniora Utama Press: Bandung

Mardikanto, Totok. 2015. Pemberdayaan Masyarakat. Alfabeta: Bandung

Sudarto, Y. 2000. Budidaya Waluh. Yogyakarta: Kanisius Sutoro, Eko. 2020. Pemberdayaan Masyarakat Desa. Diklat: Samarinda Widayati, E \& Damayanti, W. 2007.

Aneka Pengolahan dari Labu Kuning. Jakarta: Trubus Agrisrana 